\title{
The Dual Impacts of Green Credit on Economy and Environment: Evidence from China
}

\author{
Yanli Wang ${ }^{1}$, Xiaodong Lei ${ }^{1, *(\mathbb{D}}$, Dongxiao Zhao ${ }^{2}$, Ruyin Long ${ }^{1}$ and Meifen $\mathrm{Wu}^{1}$ \\ 1 School of Economics and Management, China University of Mining and Technology, Xuzhou 221116, China; \\ wangyanlims@cumt.edu.cn (Y.W.); longruyin@163.com (R.L.); wumeifen6210@163.com (M.W.) \\ 2 Business School, Beijing International Studies University, Beijing 100024, China; zxd1178778392@163.com \\ * Correspondence: xiaodLei@163.com
}

Citation: Wang, Y.; Lei, X.; Zhao, D.; Long, R.; Wu, M. The Dual Impacts of Green Credit on Economy and Environment: Evidence from China. Sustainability 2021, 13, 4574 https://doi.org/10.3390/su13084574

Academic Editor: Anna Visvizi

Received: 27 March 2021

Accepted: 16 April 2021

Published: 20 April 2021

Publisher's Note: MDPI stays neutral with regard to jurisdictional claims in published maps and institutional affiliations.

Copyright: (c) 2021 by the authors. Licensee MDPI, Basel, Switzerland. This article is an open access article distributed under the terms and conditions of the Creative Commons Attribution (CC BY) license (https:// creativecommons.org/licenses/by/ $4.0 /)$.

\begin{abstract}
Green credit is regarded as an important means to promote sustainable growth. Based on the provincial panel dataset of China from 2007 to 2017, this paper investigates the dual impacts of green credit on the economy and environment, and it establishes mediating effect models to analyze the Porter hypothesis. The results show that the green credit policy significantly improves economic performance and reduces pollutant emissions. The above results are robust to employing methods with alternative variables and instrumental variables. Second, the green credit policy contributes to innovation; that is, the green credit increases the innovation scale and improves innovation efficiency. The results of mediating effect models suggest that the Porter effect of green credit can be achieved by improving innovation efficiency. The findings of the current study indicate that the green credit policy helps achieve the win-win situation for economic goals and environmental targets.
\end{abstract}

Keywords: green credit policy; economic development; environmental pollution; Porter effect; China

\section{Introduction}

In recent years, increasingly serious environmental problems have not only threatened human beings' health [1] but also hindered the sustainable development [2]. To build a greener, more sustainable and inclusive world, countries all over the world should put in place policies and practices to deal with environmental challenges [3]. As the world's second largest economy, China has made significant contributions to the global economy while accounting for a large share of energy consumption and carbon dioxide $\left(\mathrm{CO}_{2}\right)$ emissions [4]. To battle air pollution and mitigate carbon dioxide $\left(\mathrm{CO}_{2}\right)$ emissions, China has introduced a series of environmental policies [5]. Green finance has become one of the most important policies for pollution abatement in recent years [6]. The term green finance originated from the Equator Principles (EPs) proposed by the International Finance Corporation (IFC) in 2003, which called for financial institutions to consider environmental and social factors in their investment and financing activities [7]. However, the definition of green finance is yet to reach a common agreement [8]. According to the G20 Green Finance Study Group (GFSG) [9], the green finance refers to investment and financing activities that can produce environmental benefits to support sustainable development. The green finance aims to reduce capital inflow from pollution and energy-intensive projects and put more funds into green and low-carbon industries [10]. Therefore, it is necessary for industrial sectors to take on sustainable production practices, which can effectively solve environmental problems from the source. Unlike the command-and-control environmental policies, green finance not only emphasizes the goal of environmental protection but also the better financial services to economy [11]. Consequently, the green finance may be conducive to achieving the win-win situation between economy and environment advocated by Tobin [12].

The green credit policy, one of the earliest and fastest-growing green financial instruments in China [13], incorporates environment-related risks into credit management 
frameworks and strictly prevents credit funds from flowing into energy-intensive and high-pollution industries [14]. As early as 1995, China has made relevant provisions on the implementation of environmental policies in the credit management of financial institutions. At that time, China had not formed a green financial system; the green credit policy was not been widely implemented. It was not until 2007 that China began to actively promote green credit. With the promulgation of the Guidance on Crediting for Energy Conservation and Emission Reduction, a series of documents on green credit policy were introduced. In 2012, the China Banking Regulatory Commission (CBRC) issued the Green Credit Guidelines, which is the first special document on green credit policy in China. The document comprehensively and systematically set out requirements for banks to carry out green credit, which greatly promotes the progress of green credit policy. Subsequently, China continued to improve the system construction of green credit, successively issuing relevant documents to improve green standards, performance evaluation, and risk management of green credit. The green credit in China has developed rapidly. By the end of June 2020, the balance of green credit in China has exceeded 11 trillion yuan, which is one of the highest in the world [15].

However, China's green credit policy is still in its infancy, with few theoretical and empirical studies [16]. The existing literature studied the impacts of green credit on enterprise performance [17], industrial structure [18], environmental pollution [19,20], and economic growth [21], but the results were mixed. Although some studies have found that green credit played important roles in environmental governance and economic development [20], its financial constraints hindered enterprises' performance [22-25]. In addition, most of the literature investigated the economic or environmental benefits of green credit from a single perspective without considering the dual impacts of green credit on economy and environment. Moreover, the prior research on the mechanisms of green credit is insufficient. On the basis of the Porter effect, a few papers studied the effect of green credit policy on innovation. Some scholars have found that green credit generated the Porter effect [26,27], but others have found that green credit did not generate the Porter effect [28]. Most of the literature focused on energy-intensive industries or enterprises, and to the best of our knowledge, there are few studies that explore the Porter effect of green credit policy from the macro level. Therefore, this motivates us to study the following questions. First, what are the dual impacts of green credit policy on the economy and environment? Second, can green credit policy generate the Porter effect?

To deal with the above questions, we investigate the dual impacts of green credit policy on economic development and environmental pollution, using China's provincial panel dataset from 2007 to 2017 as the research sample. First, we take the real gross domestic product per capita (PGDP) as the proxy variable for economic development and the sulfur dioxide $\left(\mathrm{SO}_{2}\right)$ emissions as an indicator for environmental pollution. Then, the econometric models are set to investigate the dual impacts of green credit policy on economy and environment. Second, with reference to the theory of Porter's hypothesis, we take innovation as mediation variable to clarify the influencing mechanism of green credit. Furthermore, we distinguish the scale and efficiency effect of innovation, respectively.

Our study may contribute to the existing literature in two ways. First, unlike other papers that study green credit policy from the single perspective of economy or environment, this paper clarifies the dual impacts of green credit policy on economy and environment. The results show that the green credit policy can reduce environmental pollution and improve economic development, which supports the significant role of green credit policy in achieving the win-win situation between economy and environment. Second, in the present study, we extend the application of the Porter hypothesis to the practice of green credit policy. From a macro perspective, green credit can generate the Porter effect; that is, the green credit contributes to innovation and thus reduces environmental pollution while promoting economic development. We further find that the Porter effect can only be triggered when green credit enhances the innovation efficiency. Therefore, the findings 
of this paper enlighten us on the need to improve efficiency when using green credit for innovation.

The remainder of this paper is organized as follows: Section 2 presents relevant literature review and develops research hypotheses. Section 3 introduces the research method. Section 4 describes and discusses the empirical results, and Section 5 draws conclusions and makes policy implications.

\section{Literature Review and Hypotheses Development}

\subsection{Green Credit Policy, Economy and Environment}

As White [29] pointed out in his paper, although the financial sectors have led to the deterioration of the natural environment in the past, they may be the key to environment protection in the future. In recent years, the rise of green finance provides opportunities to promote sustainability in financial systems and green the economy [30]. A large body of literature has focused on summarizing the concept of green finance and stressing its importance in sustainable development [31,32], laying a solid theoretical foundation for subsequent studies on green finance. For example, Montes [33] analyzed the definition and characteristics of green banking and took Mexico as a research sample to reveal the role of green lending in achieving environmental and social goals. Linnenluecke et al. [34] summarized the status quo of emerging interdisciplinary research on environmental finance and discussed the need for it in the context of sustainable economic transformation. Pan et al. [35] showed the significant roles of green finance in the green recovery after the COVID-19 pandemic. By analyzing the extensive literature on green finance, Zhang et al. [36] argued that green finance was essentially a financial issue; there was an urgent need to study green finance from financial perspectives. This motivates a lot of quantitative research on green finance.

In particular, as the fast-growing green financial instrument, green credit has received widespread attention in recent literature. Green credit is one kind of financial innovation that in contrast to traditional lending activities allocates more credit resources to green and low-carbon fields and thus promotes sustainable development [37]. However, the green projects are typically characterized by higher risk and lower rate of return than fossil fuel projects [38]. This may result in financial institutions not having sufficient economic incentives to grant green loans. As a result, some scholars argued that the implementation of green credit was less effective [39]. Worse yet, the green credit can harm economic performance. Su and Lian [22] used a quasi-natural experiment to conclude that the financial constraint of green credit was significant and reduced the economic performance of high-pollution firms. He et al. [23] also found that green credit reduced the corporate investment efficiency of renewable energy companies. Taking energy-intensive industries as a research sample, Wen et al. [24] found that the green credit policy in China has reduced the allocation efficiency of bank credit and posed negative impacts on a firm's innovation and total factor productivity. Ding [40] constructed a dynamic analysis and found that firms responded to green credit policy by simply reducing the investment scale rather than increasing the total factor productivity. Liu et al. [41] demonstrated that the punitive interest rate of green credit policy was ineffective in the upgrading of industrial structure.

On the contrary, some literature supported the effectiveness of green credit policy. In the context of the ecological civilization construction, the practice of green credit in China is characterized by the combination of a flexible market mechanism and stringent government supervision. The rising environmental risks and the promulgation of China's green regulation policies can force Chinese banks to implement green credit. It's found that the green credit had positive impacts on banks' risk management and financial performance. Cui et al. [42] found that green loans were less risky than no-green loans and thus reduced a bank's non-performing loan ratio. Yin et al. [43] showed that green lending increased the non-state-owned banks' profitability and reduced their risk. The green principles improve the level of banks' risk management, safeguard the safety of bank funds [44], and enhance the banks' capacity to seize opportunities for differentiated competition. 
With the continuous improvement of green credit system, financial innovation such as green guarantee and order financing will reduce the uncertainty of green credit [45,46]. Additionally, the green credit imposes high interest rates for high-pollution and energyintensive enterprises and increases their financial constraints [47]. Given that China's financing market is dominated by banks and bank credit is the most important source of corporate financing, green credit will reduce investment in high-pollution and energyintensive areas by reducing the scale of bank credit [48], while increasing financial support for green low carbon projects. The credit allocation of green credit helps to reduce pollution at the source to improve environmental quality [49]. At the same time, the green credit policy improves the quality of financial service to the real economy by reallocation of financial resources, adjusting industrial structure [50]. Based on above analysis, we propose the following hypothesis:

Hypothesis 1 (H1). The green credit policy contributes to economic development while reducing environmental pollution.

\subsection{Green Credit Policy and Porter Hypothesis: The Role of Innovation}

Another topic of interest is the mechanisms through which green credit works. Some emerging studies draw on the Porter hypothesis to explore the effects of green credit policy. The Porter effect posits that well-crafted environmental regulation policies can stimulate innovation and compensate for environmental costs [51]. However, there is no agreement on the existence of the Porter effect. Luo et al. [52] analyzed the effects of different environmental regulations on green innovation and found that command-and-control regulation and informal regulation improved green innovation, while market-based policies negatively affected green innovation. With regard to green credit policy, Hu et al. [26] showed that the green credit policy significantly promoted the green innovation of Chinese heavily polluting enterprises, justifying the existence of a weak version of the Porter effect. Zhang [27] arrived at a similar result and further found that the environmentally induced innovation improved the green total factor productivity. The above results support the strong version of the Porter effect. However, some scholars found that the effects of green credit policy on firm innovation were not significant. For example, Lu et al. [28] argued that the green credit played an important role in the reallocation of credit resources, but the realization of the Porter effect still needs improvement of the green credit system. Similarly, Xie and Zhang [53] found that the Green Credit Guidelines of China failed to promote the innovation of high-pollution enterprises. Taken together, it is evident that prior studies test the Porter effect of green credit from the level of enterprise. Due to the limitation of data availability, the research samples of these studies include only a small fraction of Chinese firms, such as heavy polluting enterprises or listed firms. For different types of enterprises, green credit policy may have heterogeneous impacts on innovation and economic performance. Therefore, it seems necessary to study the Porter effect of green credit policy from a more macro perspective, e.g., at the provincial level in China. Additionally, most of the literature ignores the existence of innovation failures. According to Schumpeter [54], innovation does not always lead to improved economic performance. The inappropriate increase of investment scale in innovation may lead to resource waste or crowd out funds for other profitable projects, resulting in an underutilization of capital. Therefore, it cannot improve green productivity and generate the Porter effect. As a consequence, the key to achieve the Porter effect lies in improving innovation efficiency. It requires the rational allocation of credit resources for innovation and thus promotes the green transition of enterprises while improving economic performance. On this basis, we propose the following two hypotheses:

Hypothesis 2a (H2a). The green credit policy cannot generate the Porter effect by increasing the scale of innovation. 
Hypothesis $\mathbf{2} \mathbf{b}(\mathbf{H} \mathbf{2 b})$. The green credit policy can generate the Porter effect by improving the innovation efficiency.

\section{Research Method}

\subsection{Models}

Although the existing literature has developed constructive research on green finance, it is still necessary to make quantitative analysis on green credit policy [44]. Accordingly, in order to study the dual impacts of green credit policy on the economy and environment, the econometric models are set as follows:

$$
\begin{aligned}
& \text { ECO }_{i t}=\alpha_{0}+\alpha_{1} G C_{i t}+\alpha_{2} \text { Controls }_{i t}+\varepsilon \\
& \text { POL }_{i t}=\beta_{0}+\beta_{1} G C_{i t}+\beta_{2} \text { Controls }_{i t}+\varepsilon
\end{aligned}
$$

where $i$ is province, $\boldsymbol{t}$ represents year, $E C \boldsymbol{O}_{i t}$ denotes the region economic growth, $P O L_{i t}$ represents environmental pollution emissions, $G C_{i t}$ is the proxy of green credit, Controls $s_{i t}$ represents control variables, and $\varepsilon$ represents random disturbance term. In Equation (1), the effect of green credit on the economy is tested; if the estimated coefficient $\alpha_{1}$ is significantly positive, it indicates that green credit can promote the regional economic growth of China. Similarly, in Equation (2), we investigate the impacts of green credit on China's environmental quality, and if the estimated coefficient $\beta_{1}$ is significantly negative, it can be concluded that green credit contributes to reducing the pollutant emissions.

Furthermore, referring to Wen and Ye [55], we construct the mediating effect models to study the mechanism of green credit, examining whether green credit can generate the innovation-driven effect to achieve the Porter effect. Specifically, the models are set as follows:

$$
\begin{gathered}
\text { INNO }_{i t}=\gamma_{0}+\gamma_{1} G C_{i t}+\gamma_{2} \text { Controls }_{i t}+\varepsilon \\
\text { ECO }_{i t}=\eta_{0}+\eta_{1} G_{i t}+\eta_{2} \text { INNO }_{i t}+\eta_{3} \text { Controls }_{i t}+\varepsilon \\
\text { POL }_{i t}=\theta_{0}+\theta_{1} G_{i t}+\theta_{2} \text { INNO }_{i t}+\theta_{3} \text { Controls }_{i t}+\varepsilon
\end{gathered}
$$

where $\mathbf{I N N O}_{i t}$ represents the innovation capacity, and the definitions of other variables are consistent with the benchmark model. In Equation (3), if the regression coefficient $\gamma_{1}$ is significantly positive, it indicates that green credit policy can improve innovation to some extent. Equation (4) is established to test the impacts of green credit on regional economic growth under the given level of innovation capacity, and the coefficient $\eta_{1}$ implies the direct effect of green credit on economic development, while the multiplier of coefficient $\gamma_{1}$ and $\eta_{2}$ measures the intermediary effect of innovation. In Equation (5), similarly, the mediating effect of innovation between green credit and environmental pollution is validated by the multiplier of coefficients $\gamma_{1}$ and $\boldsymbol{\theta}_{\mathbf{2}}$.

Take the mediating effect of innovation to the economic benefit of green credit as an example; the test process can be applied with reference to Wen and Ye [55]. First, the estimated coefficient $\alpha_{1}$ of Equation (1) is tested. If the coefficient is significantly positive, it indicates that the green credit can promote economic development, and then the next series of tests are needed. Otherwise, the mediation test should be stopped. Second, we test the estimated coefficients of Equations (3) and (4), respectively. If the estimated coefficients $\gamma_{1}, \eta_{1}$, and $\eta_{2}$ are statistically significant, it indicates that there exits a partial mediating effect. The full mediating effect exists when $\gamma_{1}$ and $\eta_{2}$ are significant, but $\eta_{1}$ is insignificant. Instead, if at least one of the coefficients between $\gamma_{1}$ and $\eta_{2}$ is not significant, the bootstrap method should be applied. Additionally, the above steps can be repeated to analyze the mediating effect of innovation between green credit policy and environmental pollution by the regression coefficients in Equations (2), (3) and (5). 


\subsection{Definition of Variables}

\subsubsection{Explained Variable}

On the one hand, the impact of green credit on economic development deserves attention. This study takes real gross domestic production per capita (PGDP) as the proxy to evaluate the economic benefits of green credit $\left(E C O_{i t}\right)$. On the other hand, the contribution of green credit to environmental protection can be reflected through the emissions volume of pollutants. With reference to $\mathrm{Lin}$ and $\mathrm{Wu}$ [56], the volume of sulfur dioxide $\left(\mathrm{SO}_{2}\right)$ emissions, a representative pollutant in China [57], is selected as the proxy variable for environmental pollution $\left(\boldsymbol{P O L}_{i t}\right)$.

\subsubsection{Explanatory Variable}

The main explanatory variable is green credit $\left(G C_{i t}\right)$. The statistical criterion of green credit in China varies, making it difficult to obtain accurate data of green credit. According to the prior study, the scale of green credit is mainly measured in three ways: dummy variables of green credit policy $[19,24]$, the share of credit in energy-intensive and highpollution industries [58], and the bank loan aiming at conserving energy and protecting the environment [21]. Considering that the bank credit supporting green and clean projects accounts for more than $70 \%$ of the total green credit, we set the scale of bank credit in energy-saving and environmental protection areas as the proxy variable for green credit.

\subsubsection{Mediation Variables}

In order to test the Porter effect of green credit policy, we take innovation as the mediator variable. On this basis, we employ a deeper analysis on the role of innovation from the perspectives of scale $\left(I S C_{i t}\right)$ and efficiency $\left(I T E_{i t}\right)$, respectively. With reference to Battese and Coelli [59], we adopt the stochastic frontier analysis (SFA) to calculate the technological efficiency of innovation, and the production function is set as follows:

$$
\begin{aligned}
\operatorname{LnY}_{i t}= & \lambda_{0}+\lambda_{1} L n K_{i t}+\lambda_{2} \operatorname{LnL}_{i t}+\lambda_{3} t+\lambda_{4} \operatorname{LnK} K_{i t} \times \operatorname{Ln} L_{i t}+\lambda_{5} \operatorname{Ln} K_{i t} \times t \\
& +\lambda_{6} \operatorname{Ln} L_{i t} \times t+\frac{1}{2} \lambda_{7}\left(\operatorname{LnK}_{i t}\right)^{2}+\frac{1}{2} \lambda_{8}\left(\operatorname{Ln} L_{i t}\right)^{2}+\frac{1}{2} \lambda_{9} t^{2}+v_{i t}-\mu_{i t}
\end{aligned}
$$

where $i=1, \cdots n$ represents the province and $t=1, \cdots T$ denotes the time period. $Y_{i t}$ is the number of patents applied in the current year [60]. $K_{i t}$ and $L_{i t}$ are R\&D expenditure and R\&D personnel, respectively. $\boldsymbol{v}_{i t}$ is the random disturbance term, and the inefficiency item $\mu_{i t}$ is set as follows:

$$
\mu_{i t}=\mu_{i} \exp (-\theta(t-T))
$$

In Equation (7), $\mu_{i} \sim N^{+}\left(\mathbf{0},{\sigma_{\mu}}^{2}\right)$ and $\theta$ is the parameter to be estimated by the maximum likelihood estimation method. Ultimately, the technological efficiency of innovation $\left(I_{T E}\right)$ can be obtained by Equation (8):

$$
\operatorname{ITE}_{i t}=\exp \left(-\mu_{i t}\right)
$$

\subsubsection{Control Variables}

In order to alleviate the deviation caused by missing variables, we incorporate the following control variables (Controls $s_{i t}$ ) into the study. Specifically, in Equation (1), the financial development $(F I N)$, employment rate $(E M P)$, opening degree $($ OPEN), infrastructure condition (INF), and industrial structure (STR) are included as control variables. In Equation (2), referring to the STIRPAT model [61], we set the degree of economic prosperity $(\boldsymbol{E P R})$, regional population density $(\boldsymbol{P O P})$, energy efficiency $(\boldsymbol{E F F})$, energy consumption structure $(E N E)$, urbanization $(U R B)$, and stringency of environmental regulation (ERE) as control variables. In Equation (3), the control variables are financial development $(\boldsymbol{F I N})$, infrastructure condition (INF), opening degree (OPEN), and the level of education $(E D U)$. 


\subsection{Sample and Data Sources}

As early as 2007, China has issued the Opinions on the Implementation of Environmental Protection Policies and Regulations to Prevent Credit Risks, which for the first time stressed the importance of green credit policy in environmental abatement [62]. The document encouraged the banking industry to pay attention to environmental risks, marking the milestone in the development of green credit policy in China. Considering the availability of data, we utilize the provincial database of China with the period from 2007 to 2017. The balanced panel data contains 30 provinces, excluding Tibet, Hong Kong, Macao, and Taiwan due to data availability. The data used in this study are mainly from the China Banking Industry Social Responsibility Report, China Statistical Yearbook, China Environmental Statistics Yearbook, China Urban Statistics Yearbook, China Science and Technology Statistics Yearbook, and China Financial Statistics Yearbook. To avoid the influence of outliers, we winsorize all continuous variables at the 1st and 99th percentiles, respectively. Table 1 shows the calculation method as well as the statistical description of main variables.

Table 1. The definition and descriptive statistics of variables.

\begin{tabular}{|c|c|c|c|c|c|c|c|c|}
\hline Types & Variables & Symbols & Definition & Obs. & Mean & Std.Dev. & Min. & Max. \\
\hline \multirow{2}{*}{$\begin{array}{l}\text { Explained } \\
\text { variables }\end{array}$} & Economic development & $\mathrm{ECO}$ & \multirow{2}{*}{$\begin{array}{c}\text { Natural logarithm of PGDP } \\
\text { Natural logarithm of the volume } \\
\text { of } \mathrm{SO}_{2}\end{array}$} & 330 & 10.542 & 0.568 & 9.244 & 11.714 \\
\hline & Pollutant emissions & POL & & 330 & 4.897 & 0.733 & 2.737 & 6.396 \\
\hline $\begin{array}{l}\text { Explanatory } \\
\text { variable }\end{array}$ & Green credit & GC & $\begin{array}{c}\text { Natural logarithm of green } \\
\text { credit balance }\end{array}$ & 330 & 9.654 & 0.937 & 8.135 & 11.087 \\
\hline \multirow{6}{*}{$\begin{array}{l}\text { Mediation } \\
\text { variables }\end{array}$} & \multirow[t]{2}{*}{ Innovation } & ISC & $\begin{array}{l}\text { Natural logarithm of the number } \\
\text { of invention patents }\end{array}$ & 330 & 10.447 & 1.573 & 6.669 & 13.595 \\
\hline & & ITE & $\begin{array}{l}\text { Measured according to } \\
\text { models }(6)-(8)\end{array}$ & 330 & 0.209 & 0.217 & 0.006 & 0.936 \\
\hline & Financial development & FIN & $\begin{array}{l}\text { Natural logarithm of gross } \\
\text { market value of stocks }\end{array}$ & 330 & 1.026 & 0.466 & 0.022 & 3.061 \\
\hline & $\begin{array}{l}\text { Employment rate } \\
\text { Opening degree }\end{array}$ & $\begin{array}{l}\text { EMP } \\
\text { OPEN }\end{array}$ & $\begin{array}{l}\text { Urban unemployment rate } \\
\text { Ratio of real FDI to real GDP }\end{array}$ & $\begin{array}{l}330 \\
330\end{array}$ & $\begin{array}{l}4.566 \\
-4.312\end{array}$ & $\begin{array}{l}0.039 \\
1.227\end{array}$ & $\begin{array}{l}4.220 \\
-8.318\end{array}$ & $\begin{array}{c}4.591 \\
-2.512\end{array}$ \\
\hline & Infrastructure condition & INF & $\begin{array}{l}\text { Natural logarithm of route length } \\
\text { per } 10,000 \text { people }\end{array}$ & 330 & 2.582 & 0.358 & 1.413 & 3.234 \\
\hline & Industrial structure & STR & $\begin{array}{l}\text { Share of value added of the } \\
\text { secondary sector to GDP }\end{array}$ & 330 & 0.463 & 0.081 & 0.213 & 0.582 \\
\hline \multirow{7}{*}{$\begin{array}{c}\text { Control } \\
\text { variables }\end{array}$} & Economic prosperity & EPR & Natural logarithm of PGDP & 330 & 10.542 & 0.568 & 9.244 & 11.714 \\
\hline & Population density & POP & $\begin{array}{l}\text { Natural logarithm of the ratio of } \\
\text { urban population to urban area }\end{array}$ & 330 & 7.837 & 0.443 & 6.733 & 8.669 \\
\hline & Energy efficiency & EFF & $\begin{array}{l}\text { Ratio of real GDP to } \\
\text { energy consumption }\end{array}$ & 330 & 0.932 & 0.490 & 0.303 & 2.590 \\
\hline & Energy structure & ENE & $\begin{array}{l}\text { Ratio of coal consumption to total } \\
\text { primary energy consumption }\end{array}$ & 330 & 0.428 & 0.174 & 0.114 & 0.872 \\
\hline & Urbanization & URB & $\begin{array}{l}\text { The proportion of urban } \\
\text { population }\end{array}$ & 330 & 3.963 & 0.235 & 3.453 & 4.492 \\
\hline & Environmental regulation & ERE & $\begin{array}{l}\text { Proportion of environmental } \\
\text { investment in GDP }\end{array}$ & 330 & 1.394 & 0.687 & 0.410 & 3.760 \\
\hline & Education & EDU & $\begin{array}{l}\text { Natural logarithm of the } \\
\text { education resources per capita }\end{array}$ & 330 & 0.753 & 0.511 & -0.385 & 1.782 \\
\hline
\end{tabular}

\section{Empirical Results and Discussion}

\subsection{The Dual Impacts of Green Credit on Economy and Environment}

Table 2 reports the regression results of green credit on the economy and environment. Columns (1)-(3) examine the contribution of green credit to China's economic development. Specifically, Column (1) shows the regression results of ordinary least square method (OLS), and columns (2)-(3) show the results of random effect model (RE) and fixed effect model (FE), respectively. According to the robust Hausman test (Sargan-Hansen $(\chi 2)=561.586, p$-value $=\mathbf{0 . 0 0 0})$, the latter model is determined to be more efficient. Furthermore, we employ the two-way fixed effect method to estimate the model. The estimated coefficient of green credit on economic development is significant and positive $(G C=0.392, t=20.739)$, indicating that the green credit positively 
correlates with the economic development. Similarly, we repeat the above estimation strategy to investigate how green credit affects China's environmental quality. The results of the robust Hausman test show that the fixed effect model should be accepted (Sargan-Hansen $(\chi 2)=175.338, p$-value $=0.000)$. Therefore, we adopt the two-way fixed effect model. The estimated coefficient of green credit on pollutant emissions in column (8) is significant and negative (GC $=-0.567, t=-5.027)$, which implies that the green credit can pose negative impacts on the environmental pollution. Taken together, the above findings strongly support Hypothesis 1.

Table 2. Regression results of green credit on economic development and environmental pollution.

\begin{tabular}{|c|c|c|c|c|c|c|c|c|}
\hline \multirow{3}{*}{ Variables } & \multicolumn{4}{|c|}{ ECO } & \multicolumn{4}{|c|}{ POL } \\
\hline & (1) & (2) & (3) & (4) & (5) & (6) & (7) & (8) \\
\hline & OLS & RE & FE & FE & OLS & RE & FE & FE \\
\hline \multirow[t]{2}{*}{ GC } & $0.374^{* * *}$ & $0.274^{* * *}$ & $0.259^{* * *}$ & $0.392 * * *$ & $-0.324^{* * *}$ & $-0.347^{* * *}$ & $-0.363^{* * *}$ & $-0.567^{* * *}$ \\
\hline & (13.144) & (21.705) & (19.297) & (20.739) & $(-9.098)$ & $(-8.810)$ & $(-7.661)$ & $(-5.027)$ \\
\hline \multirow[t]{2}{*}{ Constant } & $4.875 *$ & $6.839 * * *$ & $6.444^{* * *}$ & $5.095 * * *$ & $1.789 *$ & $5.066^{* *}$ & $8.673 * *$ & 3.533 \\
\hline & (1.768) & (11.759) & $(14.645)$ & $(15.120)$ & (1.851) & $(2.350)$ & $(2.070)$ & $(0.884)$ \\
\hline Controls & YES & YES & YES & YES & YES & YES & YES & YES \\
\hline Prov-FE & $\mathrm{NO}$ & YES & YES & YES & $\mathrm{NO}$ & YES & YES & YES \\
\hline Year-FE & NO & NO & NO & YES & $\mathrm{NO}$ & $\mathrm{NO}$ & $\mathrm{NO}$ & YES \\
\hline Obs. & 330 & 330 & 330 & 330 & 330 & 330 & 330 & 330 \\
\hline $\mathrm{R}^{2}$ & 0.436 & 0.035 & 0.890 & 0.974 & 0.722 & 0.677 & 0.612 & 0.851 \\
\hline
\end{tabular}

Notes: T-value in parentheses. ${ }^{*}, * *$, and ${ }^{* * *}$ denote statistical significance levels at $10 \%, 5 \%$, and $1 \%$, respectively.

\subsection{Robustness Test}

To enhance the robustness of the above empirical results, the following two methods are adopted. First, we replace the explained variables to eliminate the deviation caused by the contingency. Specifically, the economic development is measured by the natural logarithm of sales revenue per capita (INCO), and environmental pollution is expressed by the natural logarithm of smog emissions (SMOG). The regression results are shown in columns (1)-(2) of Table 3, where the estimated coefficient of green credit on economy is significantly positive and the environmental pollution is negative. The results are consistent with previous findings, indicating that green credit is beneficial for the win-win between environmental quality and economic performance.

Table 3. Regression results of robustness test.

\begin{tabular}{ccccccc}
\hline \multirow{2}{*}{ Variables } & \multicolumn{2}{c}{ Alter Variables } & \multicolumn{4}{c}{ Instrumental Variable } \\
\cline { 2 - 7 } & $\mathbf{( 1 )}$ & $\mathbf{( 2 )}$ & $\mathbf{( 3 )}$ & $\mathbf{( 4 )}$ & $\mathbf{( 5 )}$ & $\mathbf{( 6 )}$ \\
& INCO & SMOG & GC & ECO & GC & POL \\
\hline GC & $0.398^{* * *}$ & $-0.118^{* * *}$ & & $0.419^{* * *}$ & & $-1.252^{* * *}$ \\
& $(13.646)$ & $(-2.922)$ & & $(17.080)$ & & $(-6.739)$ \\
L_GC & & & $0.567^{* * *}$ & & $0.215^{* * *}$ & \\
& & & $(20.193)$ & & $(4.154)$ & \\
Constant & $-3.851^{* * *}$ & $5.184^{* * *}$ & -0.456 & $7.217^{* * *}$ & $-22.662^{* * *}$ & $-15.030^{* *}$ \\
& $(-5.701)$ & $(2.679)$ & $(-0.466)$ & $(15.787)$ & $(-4.442)$ & $(-2.103)$ \\
Controls & YES & YES & YES & YES & YES & YES \\
Prov-FE & YES & YES & YES & YES & YES & YES \\
Year-FE & YES & YES & NO & NO & NO & NO \\
Obs. & 330 & 330 & 300 & 300 & 300 & 300 \\
$R^{2}$ & 0.912 & 0.942 & 0.725 & 0.757 & 0.779 & 0.747 \\
\hline Notes: T-value in parentheses. **, and ${ }^{* * *}$ denote statistical significance levels at $5 \%$, and $1 \%$, respectively.
\end{tabular}

Second, in order to deal with the potential endogenous problems, we apply the two-stage least square (2SLS) method with one-lagged dependent variable $\left(L_{-} G C\right)$ as the instrumental variable (IV). The F-statistics of the first stage regression are far more than 
$10\left(F_{E C O}=458.454, F_{P O L}=217.587\right)$, which indicates no evidence for weak instruments problems. According to the results of the second stage in column (4) and column (6), the regression coefficient of green credit on economic development is significantly positive at the $1 \%$ level, and the regression coefficient of environmental pollution is significantly negative at the $1 \%$ level. Once again, the regression results validate the robustness of aforementioned findings.

\subsection{The Mediating Effect of Innovation}

Furthermore, it is necessary to clarify the influencing mechanism of green credit on economy and environment. In this section, we focus on the mediating role of innovation in the framework of the Porter effect. First, we examine whether scaling up innovation input can trigger the Porter effect. From the results in column (2) of Table 4, it can be seen that the regression coefficient of green credit on the scale of innovation is significant and positive, indicating that green credit contributes to the increase of innovation scale $(G C=0.774, t=18.675)$. From the results in columns (1)-(6), the mediating effect of the innovation scale is not significant at the $5 \%$ level. It indicates that green credit cannot achieve the so-called Porter effect by simply increasing the scale of innovation, and thus, Hypothesis 2a holds.

Table 4. The mediating effect of innovation scale.

\begin{tabular}{ccccccc}
\hline \multirow{2}{*}{ Variables } & $\mathbf{( 1 )}$ & $\mathbf{( 2 )}$ & $\mathbf{( 3 )}$ & $\mathbf{( 4 )}$ & $\mathbf{( 5 )}$ & $\mathbf{( 6 )}$ \\
\cline { 2 - 7 } & ECO & ISC & ECO & POL & ISC & POL \\
\hline GC & $0.392^{* * *}$ & $0.774^{* * *}$ & $0.351^{* * *}$ & $-0.567^{* * *}$ & $0.774 * * *$ & $-0.428^{* * *}$ \\
& $(20.739)$ & $(18.675)$ & $(11.486)$ & $(-5.027)$ & $(18.675)$ & $(-3.057)$ \\
ISC & & & $0.051^{*}$ & & & $-0.205^{*}$ \\
& & & $(1.807)$ & & & $(-1.976)$ \\
Constant & $5.095^{* * *}$ & $2.082^{* * *}$ & $4.978^{* * *}$ & 3.533 & $2.082 * * *$ & 1.933 \\
& $(15.120)$ & $(3.019)$ & $(13.628)$ & $(0.884)$ & $(3.019)$ & $(0.470)$ \\
Controls & YES & YES & YES & YES & YES & YES \\
Prov-FE & YES & YES & YES & YES & YES & YES \\
Year-FE & YES & YES & YES & YES & YES & YES \\
Obs. & 330 & 330 & 330 & 330 & 330 & 330 \\
$\mathrm{R}^{2}$ & 0.974 & 0.961 & 0.974 & 0.851 & 0.961 & 0.856 \\
\hline Notes: T-value in parentheses. ${ }^{*}$ and an $^{* * *}$ denote statistical significance levels at $10 \%$ and $1 \%$ respectively.
\end{tabular}

Next, we turn to test whether improving the technological efficiency of innovation can achieve the Porter effect. Table 5 reports the regression results. In column (2), the results present a significant positive relationship between green credit and innovation efficiency $(G C=\mathbf{0 . 0 1 2}, t=12.087)$, suggesting that green credit can improve innovation technological efficiency at the level of province. Similarly, the mediating analysis based on the results in columns (1)-(6) reveals that the mediating effect of innovation efficiency is significant. Specifically, according to the coefficients in column (3), the mediating effect of the innovation efficiency in boosting economic development approximately accounts for $4 \%$ of the total effect. According to the results in column (6), the mediating effect of innovation efficiency in reducing environmental pollution is about $30 \%$ of the total effect. The above results show that the strong version of the Porter effect can be realized through the green credit policy, supporting Hypothesis $2 \mathrm{~b}$. The green credit plays a role in optimizing the economy and reducing environmental pollution through the mediation of innovation efficiency. The findings suggest that under the green credit principles, achieving economic and environmental benefits rests not on the increase of innovation scale but on the capacity to promote the efficiency of innovation. 
Table 5. The mediating effect of innovation efficiency.

\begin{tabular}{ccccccc}
\hline \multirow{2}{*}{ Variables } & $\mathbf{( 1 )}$ & $\mathbf{( 2 )}$ & $\mathbf{( 3 )}$ & $\mathbf{( 4 )}$ & $\mathbf{( 5 )}$ & $\mathbf{( 6 )}$ \\
\cline { 2 - 7 } & ECO & ITE & ECO & POL & ITE & POL \\
\hline GC & $0.392^{* * *}$ & $0.012^{* * *}$ & $0.376^{* * *}$ & $-0.567^{* * *}$ & $0.012^{* * *}$ & $-0.436^{* * *}$ \\
& $(20.739)$ & $(12.087)$ & $(24.189)$ & $(-5.027)$ & $(12.087)$ & $(-4.233)$ \\
ITE & & & $1.471^{* * *}$ & & & $-14.463^{* *}$ \\
& & & $(2.967)$ & & & $(-2.051)$ \\
Constant & $5.095^{* * *}$ & $0.117^{* * *}$ & $4.868^{* * *}$ & 3.533 & $0.117 * * *$ & 5.153 \\
& $(15.120)$ & $(8.350)$ & $(10.839)$ & $(0.884)$ & $(8.350)$ & $(1.392)$ \\
Controls & YES & YES & YES & YES & YES & YES \\
Prov-FE & YES & YES & YES & YES & YES & YES \\
Year-FE & YES & YES & YES & YES & YES & YES \\
Obs. & 330 & 330 & 330 & 330 & 330 & 330 \\
$\mathrm{R}^{2}$ & 0.974 & 0.887 & 0.974 & 0.851 & 0.887 & 0.864 \\
\hline Notes: T-value in parentheses. ${ }^{* *}$, and & *** denote statistical significance levels at $5 \%$, and $1 \%$, respectively.
\end{tabular}

\section{Conclusions and Implications}

Environmental challenges have called increasing attention and demanded immediate reactions from all over the world. The green credit policy has become one of the key solutions to cope with environmental problems in China. On the basis of panel data of 30 Chinese provinces, this study investigates the dual effects of green credit on economic development and environmental pollution, and it constructs the mediating effect model to examine the Porter hypothesis. The results are as follows. First, green credit is positively correlated with regional economic development and negatively correlated with environmental pollution. The conclusion holds after robustness tests by alternative variables and the instrumental variable method. Second, the green credit contributes to regional innovation, either in terms of innovative scale or innovation efficiency. Moreover, results of mediating effect models reveal that the Porter effect of green credit can be generated by promoting innovation efficiency, thereby achieving the win-win situation between economic goals and environmental targets.

Our empirical results have important implications for researchers, practitioners, and policy makers. First, we show that the green credit policy has dual positive impacts on economic development and environmental pollution. It contributes to better understanding the effects of green credit policy. Therefore, the government should pay more attention to green credit policy, increase investment in green financial infrastructure, and design a green incentive mechanism to support the development of green credit. In addition, the financial institutions should follow the Equator Principles (Eps), consider the environmental risks, and cultivate greener financial culture. Second, we posit that improving innovation efficiency can produce the Porter effect. In order to improve the innovation efficiency of enterprises, it is necessary to set up a special green credit fund. At the same time, the supervision and management of green credit should be strengthened to improve the efficiency of capital utilization and achieve the green and low-carbon transformation at a lower cost.

There are some limitations in the present study. First, due to the limitation of data availability, we only use data from China to explore the impacts of green credit. The applicability of our conclusions in other countries and regions still needs to be further verified. Therefore, future studies can expand research samples to the global level so that the effectiveness of green credit policies can be assessed more comprehensively. Second, although this paper validates the effectiveness of green credit policy at the macro level, more micro-level issues regarding green credit deserve in-depth study. For example, the corporate social responsibility (CSR) is closely related to green credit policy. On the one hand, CSR activities affect the risk and financial performance of enterprises [63,64], which in turn affect banks' decision-making in green credit. On the other hand, the implementation of green credit policy stresses the importance of environmental risks, which can also have positive impacts on CSR. Future research can conduct more studies on the micro effects of 
green credit from the perspective of CSR. Moreover, the research framework of the Porter effect needs to be further enriched. The emergence of new environmental policies may challenge the prior findings on the Porter effect. In addition, the innovation activities of enterprises are increasingly complex and diverse. Therefore, future research should consider different forms of innovation activities, such as eco-innovation and collaborative innovation $[65,66]$. In addition, the heterogeneity of the Porter effect under different environmental policies can be of great value to be explored.

Author Contributions: Conceptualization, Y.W. and X.L.; Data curation, X.L.; Funding acquisition, Y.W. and R.L.; Methodology, X.L. and D.Z.; Software, X.L.; Supervision, R.L.; Validation, Y.W., X.L. and D.Z.; Visualization, M.W.; Writing—original draft, Y.W. and X.L.; Writing-review and editing, Y.W., X.L. and D.Z. All authors have read and agreed to the published version of the manuscript.

Funding: This study was financially supported by the Key Project of National Social Science Foundation of China (No. 18AZD014), the Major Project of National Social Science Foundation of China (No. 19ZDA107), the Project of National Social Science Foundation of China (No. 20BJY079) and the Ministry of Education of Humanities and Social Science Project of China (No. 19YJA790086).

Institutional Review Board Statement: Not applicable.

Informed Consent Statement: Not applicable.

Data Availability Statement: The data presented in this study are available on request from the corresponding author.

Acknowledgments: We would like to thank the editor and the anonymous reviewers for constructive and insightful comments.

Conflicts of Interest: The authors declare no conflict of interest.

\section{References}

1. Hollingsworth, A.; Konisky, D.; Zirogiannis, N. The health consequences of excess emissions: Evidence from Texas. J. Environ. Econ. Manag. 2021, in press. [CrossRef]

2. Calel, R.; Chapman, S.C.; Stainforth, D.A.; Watkins, N.W. Temperature variability implies greater economic damages from climate change. Nat. Commun. 2020, 11, 5028. [CrossRef] [PubMed]

3. UNEP (United Nations Environment Programme). UN Environment Assembly Sets Stage for Green Recovery. Available online: https:/ / www.unep.org/news-and-stories/story/un-environment-assembly-sets-stage-green-recovery (accessed on 15 February 2021).

4. IEA (International Energy Agency). Global Energy \& CO2 Status Report 2019. Available online: https://www.iea.org/reports/ global-energy-co2-status-report-2019 (accessed on 26 March 2019).

5. Qian, H.; Xu, S.; Cao, J.; Ren, F.; Wei, W.; Meng, J.; Wu, L. Air pollution reduction and climate co-benefits in China's industries. Nat. Sustain. 2021, in press. [CrossRef]

6. Huang, H.; Zhang, J. Research on the Environmental Effect of Green Finance Policy Based on the Analysis of Pilot Zones for Green Finance Reform and Innovations. Sustainability 2021, 13, 3754. [CrossRef]

7. Scholtens, B.; Dam, L. Banking on the equator. Are banks that adopted the Equator Principles different from non-adopters? World Dev. 2007, 35, 1307-1328. [CrossRef]

8. Lindenberg, N. Definition of Green Finance. Available online: https:/ / ssrn.com/abstract=2446496 (accessed on 15 April 2014 ).

9. G20 Sustainable Finance Study Group Document Repository. G20 Green Finance Synthesis Report 2016. Available online: http:/ / unepinquiry.org/g20greenfinancerepositoryeng (accessed on 5 September 2016).

10. Ling, S.; Han, G.; An, D.; Hunter, W.C.; Li, H. The Impact of Green Credit Policy on Technological Innovation of Firms in Pollution-Intensive Industries: Evidence from China. Sustainability 2020, 12, 4493. [CrossRef]

11. Wang, Y.; Zhi, Q. The role of green finance in environmental protection: Two aspects of market mechanism and policies. Energy Procedia 2016, 104, 311-316. [CrossRef]

12. Tobin, P. Economics from zero-sum to win-win. Nat. Clim. Chang. 2020, 10, 386-387. [CrossRef]

13. Hong, W.; Liu, X.; Ye, Y.; Li, X.; Shi, J.; Lan, X.; Dai, B.; Liu, J. Research on Green Finance Theory and Practice. Financ. Regul. Res. 2021, in press. [CrossRef]

14. Cao, Y.; Zhang, Y.; Yang, L.; Li, R.Y.M.; Crabbe, M.J.C. Green Credit Policy and Maturity Mismatch Risk in Polluting and Non-Polluting Companies. Sustainability 2021, 13, 3615. [CrossRef]

15. PBC (The People's Bank of China). Supporting Low Carbon Development with Green Finance Video Speech at the Singapore FinTech Festival (SFF) 2020. Available online: http:/ / www.pbc.gov.cn/en/3688110/3688175/4141703/index.html (accessed on 9 December 2020). 
16. Wang, L.; Qiu, X.M.; Zhang, X.X.; Ma, R.H.; Jiang, Y.H. Development status and environmental impact evaluation of China's green finance. Appl. Ecol. Environ. Res. 2019, 17, 12245-12258. [CrossRef]

17. Chen, Y.; Ma, Y. Does green investment improve energy firm performance? Energy Policy 2021, 153, 112252. [CrossRef]

18. Hu, Y.; Jiang, H.; Zhong, Z. Impact of green credit on industrial structure in China: Theoretical mechanism and empirical analysis. Environ. Sci. Pollut. Res. 2020, 27, 10506-10519. [CrossRef] [PubMed]

19. Sun, J.X.; Wang, F.; Yin, H.T.; Zhang, B. Money talks: The environmental impact of China's green credit policy. J. Policy Anal. Manag. 2019, 38, 653-680. [CrossRef]

20. Nabeeh, N.A.; Abdel-Basset, M.; Soliman, G. A model for evaluating green credit rating and its impact on sustainability performance. J. Clean. Prod. 2021, 280, 124299. [CrossRef] [PubMed]

21. Wen, S.; Lin, Z.; Liu, X. Green Finance and Economic Growth Quality: Construction of General Equilibrium Model with Resource Constraints and Empirical Test. Chin. J. Manag. Sci. 2021, in press. [CrossRef]

22. Su, D.; Lian, L. Does green credit policy affect corporate financing and investment? Evidence from publicly listed firms in pollution-intensive industries. J. Financ. Res. 2018, 12, 123-137.

23. He, L.; Zhang, L.; Zhong, Z.; Wang, D.; Wang, F. Green credit, renewable energy investment and green economy development: Empirical analysis based on 150 listed companies of China. J. Clean. Prod. 2019, 208, 363-372. [CrossRef]

24. Wen, H.; Lee, C.C.; Zhou, F. Green credit policy, credit allocation efficiency and upgrade of energy-intensive enterprises. Energy Econ. 2021, 94, 105099. [CrossRef]

25. Zhang, D.; Vigne, S.A. The causal effect on firm performance of China's financing-pollution emission reduction policy: Firm-level evidence. J. Environ. Manag. 2021, 279, 111609. [CrossRef] [PubMed]

26. Hu, G.; Wang, X.; Wang, Y. Can the green credit policy stimulate green innovation in heavily polluting enterprises? Evidence from a quasi-natural experiment in China. Energy Econ. 2021, 98, 105134. [CrossRef]

27. Zhang, D. Green credit regulation, induced R\&D and green productivity: Revisiting the Porter Hypothesis. Int. Rev. Financ. Anal. 2021, 101723. [CrossRef]

28. Lu, J.; Yan, Y.; Wang, T. The Microeconomic Effects of Green Credit Policy: From the Perspective of Technological Innovation and Resource Reallocation. China Ind. Econ. 2021, 1, 174-192. [CrossRef]

29. White, M.A. Environmental finance: Value and risk in an age of ecology. Bus. Strateg. Environ. 1996, 5, 198-206. [CrossRef]

30. Dikau, S.; Volz, U. Central bank mandates, sustainability objectives and the promotion of green finance. Ecol. Econ. 2021, 184, 107022. [CrossRef]

31. Glomsrod, S.; Wei, T.Y. Business as unusual: The implications of fossil divestment and green bonds for financial flows, economic growth and energy market. Energy Sustain. Dev. 2018, 44, 1-10. [CrossRef]

32. Karpf, A.; Mandel, A. The changing value of the 'green' label on the US municipal bond market. Nat. Clim. Chang. 2018, 8, 161-165. [CrossRef]

33. Montes, L. Financing sustainable development in Mexico through alternative banks or "green banks". J. Struct. Financ. 1998, 4, 67-71. [CrossRef]

34. Linnenluecke, M.K.; Smith, T.; McKnight, B. Environmental finance: A research agenda for interdisciplinary finance research. Econ. Model. 2016, 59, 124-130. [CrossRef]

35. Pan, D.; Chen, C.; Grubb, M.; Wang, Y. Financial Policy, Green Transition and Recovery after the COVID-19. Available online: https: / / ssrn.com/abstract=3719695 (accessed on 22 February 2021).

36. Zhang, D.Y.; Zhang, Z.W.; Managi, S. A bibliometric analysis on green finance: Current status, development, and future directions. Financ. Res. Lett. 2019, 29, 425-430. [CrossRef]

37. Ba, S.; Yang, C.; Yao, S. Review on the research progress of China's green finance. J. Financ. Dev. Res. 2018, 6, 3-11. [CrossRef]

38. Taghizadeh-Hesary, F.; Yoshino, N. The way to induce private participation in green finance and investment. Financ. Res. Lett. 2019, 31, 98-103. [CrossRef]

39. Biswas, N. Sustainable green banking approach: The need of the hour. Bus. Spectr. 2011, 1, 32-38.

40. Ding, J. Green credit policy, credit resources allocation and strategic response of enterprises. Econ. Rev. 2019, 4, 62-75. [CrossRef]

41. Liu, J.Y.; Xia, Y.; Fan, Y.; Lin, S.M.; Wu, J. Assessment of a green credit policy aimed at energy-intensive industries in China based on a financial CGE model. J. Clean. Prod. 2017, 163, 293-302. [CrossRef]

42. Cui, Y.; Geobey, S.; Weber, O.; Lin, H. The impact of green lending on credit risk in China. Sustainability 2018, 10, 2008. [CrossRef]

43. Yin, W.; Zhu, Z.; Kirkulak-Uludag, B.; Zhu, Y. The determinants of green credit and its impact on the performance of Chinese banks. J. Clean. Prod. 2021, 286, 124991. [CrossRef]

44. Zhang, B.; Yang, Y.; Bi, J. Tracking the implementation of green credit policy in China: Top-down perspective and bottom-up reform. J. Environ. Manag. 2011, 92, 1321-1327. [CrossRef]

45. Wang, Y.; Pan, D.; Yu, P.; Liang, X. China's incentive policies for green loans: A DSGE approach. J. Financ. Res. 2019, 11, 1-18. [CrossRef]

46. Wang, C.; Li, X.W.; Wen, H.X.; Nie, P.Y. Order financing for promoting green transition. J. Clean. Prod. 2021, $283,125415$. [CrossRef]

47. Liu, X.H.; Wang, E.X.; Cai, D.T. Green credit policy, property rights and debt financing: Quasi-natural experimental evidence from China. Financ. Res. Lett. 2019, 29, 129-135. [CrossRef] 
48. Chen, Q. Has China's green credit policy been implemented? An analysis of loan scale and costs based on "Two Highs and One Surplus" enterprises. Contemp. Financ. Econ. 2019, 3, 118-129. [CrossRef]

49. Cai, H.; Wang, X.; Tan, C. Green credit policy, incremental bank loans and environmental protection effect. Account. Res. 2019, 3, $88-95$.

50. Xu, S.; Zhao, X.; Yao, S. Analysis on the effect of green credit on the upgrading of industrial structure. J. Shanghai Univ. Financ. Econ. 2018, 20, 59-72. [CrossRef]

51. Porter, M.E.; Der Linde, C.V. Toward a New Conception of the Environment-Competitiveness Relationship. J. Econ. Perspect. 1995, 9, 97-118. [CrossRef]

52. Luo, Y.; Salman, M.; Lu, Z. Heterogeneous impacts of environmental regulations and foreign direct investment on green innovation across different regions in China. Sci. Total Environ. 2021, 759, 143744. [CrossRef]

53. Xie, Q.; Zhang, Y. Green credit policies, supporting hand and innovation transformation of enterprises. Sci. Res. Manag. 2021, 42, 124-134. [CrossRef]

54. Schumpeter, J.A. The Theory of Economic Development: An Inquiry into Profits, Capita I, Credit, Interest, and the Business Cycle, 1st ed.; Routledge: New York, NY, USA, 2017. [CrossRef]

55. Wen, Z.; Ye, B. Analyses of mediating effects: The development of methods and models. Adv. Psychol. Sci. 2014, 22, 731-745. [CrossRef]

56. Lin, B.; Wu, R. The dilemma of paraxylene plants in China: Real trouble for the environment? Sci. Total Environ. 2021, 779,146456 [CrossRef] [PubMed]

57. Hang, Y.; Wang, Q.W.; Wang, Y.Z.; Su, B.; Zhou, D.Q. Industrial $\mathrm{SO}_{2}$ emissions treatment in China: A temporal-spatial whole process decomposition analysis. J. Environ. Manag. 2019, 243, 419-434. [CrossRef]

58. Wang, K.; Sun, X.; Wang, F. Green finance, financing constrains and the investment of polluting enterprise. Contemp. Econ. Manag. 2019, 41, 83-96. [CrossRef]

59. Battese, G.E.; Coelli, T.J. Frontier production functions, technical efficiency and panel data: With application to paddy farmers in India. J. Prod. Anal. 1992, 3, 153-169. [CrossRef]

60. Jin, P.Z.; Peng, C.; Song, M.L. Macroeconomic uncertainty, high-level innovation, and urban green development performance in China. China Econ. Rev. 2019, 55, 1-18. [CrossRef]

61. York, R.; Rosa, E.A.; Dietz, T. STIRPAT, IPAT and ImPACT: Analytic tools for unpacking the driving forces of environmental impacts. Ecol. Econ. 2003, 46, 351-365. [CrossRef]

62. Xu, X.; Li, J. Asymmetric impacts of the policy and development of green credit on the debt financing cost and maturity of different types of enterprises in China. J. Clean. Prod. 2020, 264, 121574. [CrossRef]

63. Dunbar, C.G.; Li, Z.F.; Shi, Y. Corporate Social (Ir)responsibility and Firm Risk: The Role of Corporate Governance. Available online: https:/ / ssrn.com/abstract=3791594 or http:/ / dx.doi.org/10.2139/ssrn.3791594 (accessed on 23 February 2021).

64. Li, Z.; Minor, D.B.; Wang, J.; Yu, C. A learning curve of the market: Chasing alpha of socially responsible firms. J. Econ. Dyn. Control 2019, 109, 103772. [CrossRef]

65. Geng, D.; Lai, K.; Zhu, Q. Eco-innovation and its role for performance improvement among Chinese small and medium-sized manufacturing enterprises. Int. J. Prod. Econ. 2021, 231, 107869. [CrossRef]

66. Wang, S.; Wang, X.; Lu, F.; Fan, F. The impact of collaborative innovation on ecological efficiency-empirical research based on China's regions. Technol. Anal. Strateg. Manag. 2021, 33, 242-256. [CrossRef] 